Egyptian Journal for Aquaculture

P-ISSN: 2090-7877

E-ISSN: 2636-3984

www.eja.journals.ekb.eg/

Eid et al., 2020; 10 (3):96-114

DOI: $10.21608 /$ eja.2020.43323.1036

\title{
Stocking density, Survival rate and Growth performance feed utilization and economic evaluation of Litopenaeus vannamei , in different cultured shrimp farms in Suez Canal Region
}

Eid, A.E1, Ali, B.A1, Esayed, K.A1 and Gad.S,M1, Mohamed, k., Khames2, Doaa, K., Khames2

${ }^{1}$ Department of Animal Production and fish Resources-Faculty of Agriculture-Suez Canal University.Ismailia41522.Egypt.

${ }^{2}$ Central laboratory for aquaculture research (CLAR) -Abbasa AboHammad - Sharquia . Agriculture Research Center (ARC)

Received: Sept. 27, 2020; Accepted: Oct.27, 2020 published: 2020 Vol.10 (3):96-114

\section{ABSTRACT}

Two studies were conducted to evaluate growth performance, feed utilization, survival rate and the economic cost of white shrimp ( $P$. vannamei) in Suez Canal region. The first study was conducted in Eldebba farm in western region of Port Said Governorate in collaboration with a private fish farm. The second study was conducted in Suez Canal Fish Farm. The pond was stocked with white shrimp ( $P$. vannamei) at the rate of 70000 PL 26 / feddan in eldebba Farm. In Suez Canal Farm the ponds stocked with $150000 \mathrm{PL} 26$ / feddan white shrimp (P. vannamei) with average initial $0.002 \mathrm{~g}$ in both Farms. A good quality (38\% protein) commercial feed was provided. Growth performance, feed utilization, survival rate and comical evaluation were the best in Eldebba farm than Suez Canal farm.

It could be concluded that stocking white shrimp at density 70000 / feddan was the best in terms of growth performance, feed utilization, survival and economic evaluation under this experimental conditions.

Key word: Litopenaeus vannamei- Stocking density - Water quality Growth performance- Feed utilization- Survival rate- Economic evaluation. 


\section{Introduction}

In Egypt, shrimp culture has a fluctuated progression. Shrimp culture in Egypt dates back to the early 1980s, where the first shrimp farm was established near Alexandria (Sadek et al., 2002). Although shrimp culture is profitable, but shrimp diseases is still one of the major problems. Shrimp's origin is from the eastern Pacific waters. In practice of shrimp culture, shrimp farmers often use their habit and experience, including the harvest time (Nour et al., 2004). Shrimp farming is one of the majority gainful and fast-growing segments of the aquaculture industry (Tacon, 2002). Due to the economic importance of penaeid shrimp worldwide, particularly in aquaculture, a huge attempt to know the enlargement ecology of Penaeus spp. has been made in recent years. This includes studies on the influence of environmental factors such as temperature (López- Martínez et al., 2003), salinity (Lemos et al., 2001) on shrimp growth.

Litopenaeus vannamei is the most important penaeid shrimp species farmed earth (Alcivar Warren et al., 2007), which is considered the most widely cultured shrimp in the western hemisphere were the species contributes to regarding $90 \%$ of the total shrimp culture, as it represents the most commonly cultured shrimp in central and south American countries (Wurmann et al., 2004).

Aquaculture can be performed within semi-intensive and intensive systems, which both cultivation systems depends on one characteristic which is the stocking density (Neal $\boldsymbol{e t}$ al., 2010). An increase in farmed shrimp production can be achieved by increasing stocking density but this requires an increase in feed input which may degrade water quality. The optimal stocking density varies depending on the farm system and management practices. Stocking densities range 1-3 shrimp $/ \mathrm{m}^{2}$ in extensive, $10-50 \mathrm{shrimp} / \mathrm{m}^{2}$ in semi-intensive, and up to $160 \mathrm{shrimp} / \mathrm{m}^{2}$ in intensive farming systems. Water exchange minimizes eutrophication without requiring additional aeration. Water exchange is required for intensive cultures to prevent phytoplankton blooms and agglomeration of toxic metabolites not assimilated by phytoplankton. Mechanical aeration (mainly at night) minimizes circadian changes of dissolved oxygen (Mena-Herrera et al., 2006). A balanced food supplement improves growth and together with aeration, is considered as the most commonly factors affected intensive culture. As shrimp aquaculture technology advances, greater efficiency with respect to water conditions, survival, growth, and yield is required. Farm yields have increased markedly due to technological advances. Density is a parameter that can affect the growth 
and survival rate of cultured species (Gaber et al., 2012) stated that the density and performance of penaeid shrimp have positive correlation. The optimum density of the penaeid shrimp has been reported even though it varies greatly, such as 9-12 ind m-2 for Penaeus semisulcatus (Zaki et al., 2004), 10 ind $\mathrm{m}^{-2}$ for $P$. indicus (Sivanandavel and Soundarapandian 2010), 10 ind $\mathrm{m}^{-2}$ for Fenneropenaeus merguiensis (Anand et al., 2014), and 10-15 ind $\mathrm{m}^{-2}$ for P. monodon (Hossain et al., 2013). While $L$. vannamei has been widely reported although the density and culture systems used are very diverse Gamal et al., (2018). When the post-larvae are grown in the hatchery till the juvenile stage and thereafter stocked in ponds, the survival rates could be expected to enhance compared to a system where the post-larvae are directly stocked in ponds (Aquacop, 1984). Several authors described concerning the growth in shrimp culture systems based on stocking density (Maguire and Leedow 1983) and some authors include reported an inverse relationship between growth and stocking density (Daniels et al., 1995). The objective of this work was to evaluate the water quality parameters, survival, growth performance, feed utilization and economic production of $L$. vannamei cultures in the different aquaculture shrimp farms with different stocking densities and different hector levels.

\section{Materials and Methods}

\section{Study Site and Experimental Units}

Two studies were conducted to evaluate growth performance, feed utilization, survival and the economic production of white shrimp $(P$. vannamei) in Suez Canal region. The first study was conducted in Eldebba farm in western region of Port Said Governorate collaboration with a private fish farm, with a total pond area of one feddan / pond. The water depth of about 1.25 between May to august 2020. The water is a brackish due to the mixing of Mediterranean Sea water and water from Lake Manzala. Productivity was based on the natural productivity of the ponds hence the experimental ponds were kept free from any shading throughout the day.

\section{Pond preparation}

Pond preparation procedures were briefly, which the ponds were dried for one month and the top soil was scraped and removed, ploughed and filled with pre-chlorinated (12 ppm available chlorine) water from a reservoir pond. Aerators were deployed in each pond according to the SD of the pond at the rate of one paddle wheel aerator (1 HP motor) for 1 lakh PL. 


\section{Water quality}

In the first study water exchange rate was one third of pond's water every three days, while in the second study water exchange rate was half of the pond's water every four days. Sampling for physicochemical parameters was done once a week between 09.00 and 12:00 h from specific points of the pond at a depth of $20-30 \mathrm{~cm}$ below the surface.

A mercury thermometer was used to measure water temperature $\left({ }^{\circ} \mathrm{C}\right)$, while salinity (psu) was measured with a salinometer. Digital electronic meters (Model YSI-58, USA and Jenway Model-3020) were used to measure Dissolved Oxygen (DO) $\left(\mathrm{mg}^{-1}\right)$ and $\mathrm{pH}$ on site, respectively, according to the standard procedures and methods as defined in APHA (1998). Nitrite $\left(\mathrm{NO}_{2}\right)$ and ammonia nitrogen $\left(\mathrm{NH}_{3}-\mathrm{N}\right)$ levels were analyzed spectrophotometrically at 10 days intervals (Thermo Spectra, USA) following standard procedures (APHA, 1998)

\section{White shrimp Stocking and Sampling}

The post larvae of white shrimp ( $P$. vannamei) were obtained from private white shrimp hatchery in April. The pond was stocked with white shrimp (P. vannamei) at the rate of 70000 PL 26 / feddan in Eldebba PortSaied Governorate, while In Suez Canal ponds stocked with 150000 PL 17 / feddan white shrimp ( $P$. vannamei) with average initial $0.002 \mathrm{~g}$ in both farms.

In the first study four random samples of the shrimp were taken during the study period including the initial sample. Weight of the shrimps was measured using a top loading balance with an accuracy of $0.1 \mathrm{~g}$. At the end of experiment, the pond was harvested and a complete census of all white shrimp ( $P$. vannamei) was done, where all the harvested individuals were counted; weighed and all measurements was taken. To ensure complete harvest, the white shrimp ( $P$. vannamei) were harvested initially by netting and any remaining individuals harvested by complete draining of the earthen ponds and hand picking any white shrimp (P. vannamei) in the ponds. Total production, survival rate and final harvest size in each pond were assessed at the time of harvest $0.1 \mathrm{~g}$.

\section{Feeding white shrimp (P. vannamei)}

A good quality (38 \% protein) commercial feed from Skretting Egypt Company (Table 1$)$ was provided 3 times a day $(06.00 \mathrm{hrs}, 11.00 \mathrm{hrs}, 17.00$ hrs,) by broadcasting from a boat as per the feeding schedule given by the feed manufacturer. Check trays were used to monitor feed consumption after $2 \mathrm{~h}$ of feed application in Eldebba and Suez Canal farm. Supplied in feeding trays $(36 \mathrm{~cm}$ in diameter) used for adjusting the daily food ration 
according to the apparent consumption observed on the feeding trays (Clifford, 1997).

Table (1). Proximate composition (\% dry matter)

\begin{tabular}{|l|c|}
\hline Items & $\%$ \\
\hline Moisture & 7.45 \\
\hline Crude protein & 37.92 \\
\hline Crude lipid & 6.5 \\
\hline Ash & 9.7 \\
\hline NFE & 45.88 \\
\hline Gross energy & 440.65 \\
\hline
\end{tabular}

Based on 5.1, 9.1 and 4.1 for protein, lipid and carbohydrate respectively (NRC, 1993)

\section{Growth Performance Parameters}

At the end of the experimental period, the following growth and feed utilization indices were calculate : weight gain (WG), Average daily gain (ADG) specific growth rate (SGR), feed conversion ratio (FCR), feed efficiency ratio (FER) and protein efficiency ratio (PER) using the following formulas :

Weight gain $(\mathbf{W G})=$ final average weight $\left(\mathrm{W}_{2}\right) \mathrm{g}-$ initial average weight $\left(\mathrm{W}_{1}\right) \mathrm{g}$

Averag daily gain $(\mathbf{A D G})=\left(\mathrm{W}_{2}-\mathrm{W}_{1}\right) / \mathrm{T}$

Where $\mathbf{W}_{\mathbf{1}}=$ the initial live body weight $(\mathrm{g}), \boldsymbol{\&} \mathbf{W}_{\mathbf{2}}=$ the final live body weight $(\mathrm{g})$

$\mathrm{T}=$ the time in days

Specific growth rate $(\mathbf{S G R})=\left(\ln \mathrm{W}_{2}-\ln \mathrm{W}_{1}\right) / \mathrm{T} * 100$

$\mathbf{l n}=$ natural logharetm $\quad \& \quad \mathbf{T}=$ feeding period (days).

Feed conversion ratio $($ FCR $)=$ Dry weight of feed intake $(\mathrm{g}) /$ wet weight gain of fish $(\mathrm{g})$.

Protein efficiency ratio $(\mathbf{P E R})=$ weight gain by fish / protein intake .

Where protein intake $=$ protein $(\%)$ in feed $*$ total weight of diet consumed / 100

Total weight at stocking $\mathrm{Kg} /$ feddan $=$ No. of shrimp stocked $\mathrm{X}$ Average weight at stocked 
Total weight at Harvest $\mathrm{Kg} / \mathrm{feddan}=$ No. of shrimp at harvest $\mathrm{X}$ Average weight at harvest

Net Production $=$ Total weight at Harvest $\mathrm{Kg} /$ feddan - Total weight at stocking $\mathrm{Kg} /$ feddan

The feed conversion ratio (FCR) is expressed as the proportion of dry food fed required per unit live weight gain of fish

\section{Survival rates $(\%)$}

Survival rates (\%) were estimated as: No. of white shrimp harvested / No. of white shrimp stocked $* 100$. Net production $\left(\mathrm{kg}\right.$ feddan $\left.{ }^{-1}\right)$ was calculated by deducting the biomass stocked from the biomass harvested.

The mean fish weight $(\mathrm{g})$ was determined in terms of gain in weight:

$\mathrm{GW}=\left(\mathrm{W}_{2}-\mathrm{W}_{1}\right) / \mathrm{W}_{1} \mathrm{x} 100$

Where,

\section{Economic Analysis Methodology}

Fish production information

- White shrimp costs and quantities

- $\quad$ Feeding source, costs and quantities

- $\quad$ Pond aeration

- Labor

- Rent

- $\quad$ Shrimp production

PL cost $=$ No. X price of each

Feed cost $=$ amount of feed $\mathrm{X}$ price

Total production $(\mathrm{kg} /$ feddan $)=$ weight of white shrimp No of at Harvest $\mathrm{X}$ average body weight

Total income LE feddan = Total production $(\mathrm{kg} /$ feddanX price of $\mathrm{Kg}$ Net return LE feddan $=$ Total income LE feddan- Total cost

A simple economic analysis was performed to estimate the profitability from this experiment. Total investment costs were calculated and the net revenue was determined by the difference between the gross revenue and the total investment costs. This analysis was based on farm gate prices of meager and current local market prices expressed in Egyptian LE. 


\section{Statistical Analysis}

Statistical analysis (paired t- test) was performed using the statistical software SPSS version 16. one-way ANOVA and any difference at $5 \%$ level of significance. Kachigan (1991)

\section{Results and discussion}

\section{Physico-chemical parameters of water}

Many water quality parameters are interrelated and interact with each other (Xu and Boyd, 2016), and changes in one variable give insight about changes in a related variable. The physical parameters of water play vital role in the culture systems, maintenance of water quality was essential for optimum growth and survival of shrimp, which excess feeds, fecal matter and metabolites will exert a very influence on the water quality of shrimp farms (Soundarapandian and Gunalan, 2008). Physico-chemical parameters of water recorded in Eldebba and Suez Canal farm throughout the experimental period (120 days) are given in Table 2. All the parameters were within the favorable range required for white leg shrimp farming. Temperature fluctuated considerably in different seasons from $24^{\circ} \mathrm{C}$ to $33^{\circ} \mathrm{C}$ in Eldebba farm, while the range of temperature degrees in Suez canal farm was $24-32^{\circ} \mathrm{C}$. (Fast and Lannan 1992) stated most excellent shrimp growth was experiential in a temperature ranged from $24-32^{\circ} \mathrm{C}$ during the culture period the temperature was recorded between $25-30^{\circ} \mathrm{C}$. The $\mathrm{pH}$ of pond water is influenced by many factors, including $\mathrm{pH}$ of source water, acidity of bottom soil and shrimp culture inputs and biological activity. $\mathrm{pH}$ of the pond's water was always within the acceptable range $(8.4-9.00)$ for shrimp farming in Eldebba farm and (7.3 - 8.4) in Suez Canal farm, the results obtained from the present experiment was in consistent with (Cohen et al., 2005), who stated that, the proper value of $\mathrm{pH}$ for optimal performance in penaeids family is 7-9. (Wang et al. 2004) reported that, the $\mathrm{pH} 7.6$ to 8.6 is favor for L. vannamei culture. The water quality measured throughout the experimental period 120 days was within the adequate range for the growth and survival of Penaeus vannamei (Boyd, 2015). The dissolved oxygen level in all treatments was above $5 \mathrm{mg} \mathrm{L}^{-1}$, which is considered adequate for growth (Garza de Yta $\boldsymbol{e t}$ al., 2004). Dissolved oxygen values were well above the minimum requirement (4.5 -5.00 ppm) and 5-7 in Eldebbal and Suez Canal farm for shrimp farming (Boyd and Arlow, 1992; Gicos, 1993).

The salinity plays a major role in the water quality parameters. The $L$. vanname $i$ though it is a uryhaline species it can tolerate the wide range of salinity between 2 and 45 ppt (Samocha et al., 1999, Boyd et al., 
2015). Table (2). Water parameters measured in experimental treatments for white shrimp P. monodon in Eldebba and Suez Canal farm throughout the experimental period (120 days).

\begin{tabular}{|l|c|c|}
\hline Prameters & Eldebba farm & $\begin{array}{c}\text { Suez Canal } \\
\text { farm }\end{array}$ \\
\hline Temperature $\left({ }^{\circ} \mathrm{C}\right)$ & 24 to 33 & $24-32$ \\
\hline Dissolved oxygen $(\mathrm{mg} / \mathrm{L})$ & $4.50-5.00$ & $5-7$ \\
\hline $\mathrm{pH}$ & 8.4 to 9.0 & $7.3-8.4$ \\
\hline Salinity $(\mathrm{ppt})$ & 36 to $44 \mathrm{ppt}$ & $16-18$ \\
\hline Nitrite $(\mathrm{mg} / \mathrm{L})$ & $4.08 \pm 1.6$ & $3.2 \pm 4.10$ \\
\hline Nitrate $(\mathrm{mg} / \mathrm{L})$ & $4.77 \pm 2.12$ & $2.00 \pm 3.8$ \\
\hline NH 3 & 0.002 & 0.002 \\
\hline Water productivity $($ Secchi disc) & 25 to $35 \mathrm{~cm}$ & $20-25$ \\
\hline
\end{tabular}

Variation in salinity in the present study (36 - $44 \mathrm{ppt})$ and $(16-18)$ for Eldebba and Suez Canal farms, respectively appears to play only minimal role in the growth and survival of L. vannamei, as (Araneda et al., 2008) reported successful production of $L$. vannamei even in freshwater systems. (Ponce-Palafox et al., 1997) reported the optimum salinity for $L$. vannamei cultivated in Mexico is 33-40\%. It is further explained that under certain conditions individual growth rates may be slowed down and also rapidly, depending on the area of culture such as aquaculture, brackish water and freshwater (low salinity). In addition, other factors such as water temperature, initial and final weight of individuals, and feed types also play an important role in the growth of organism. Nitrite-N level in water was well below the toxic limits reported for this species by (Lin and Chen 2003). Ammonia- $\mathrm{N}$ was also within the tolerance limit reported by (Lin and Chen 2001). Altogether the water quality parameters were not varying substantially during the entire study period nullifying their influence on the performance of the species. Nitrite values $(4.08 \pm 1.6)$ and $(3.2 \pm 4.1)$ $\mathrm{mg} / \mathrm{L}$, Nitrate $(4.77 \pm 2.12)$ and $(2 \pm 3.8) \mathrm{mg} / \mathrm{L}$ and Secchi disc 25 to 35 $\mathrm{cm}$ and 25-30 for Eldebba and Suez Canal Farms in agreement with (Boyd and Arlow, 1992).

\section{Growth Performances:}

Growth Performances parameters for both Eldebba and Suez Canal farms is shown in Table (3). The average initial body weight was 2.5 (g) 
for both farms. Generally the final body weight, weight gain, weight gain percentage, SGR and survival rate was significantly higher in Eldebba farm than Suez Canal farm. Similar results was obtained by (Rosas et al., 2001) who reported that, daily body increase of 0.04 and $0.13 \mathrm{~g}$ for 0.3 and $1.5 \mathrm{~g}$ sized groups of L. vannamei, respectively.(Xia et al., 2010) also reported a daily body increase of approximately $0.10 \mathrm{~g}$ in $6.2 \mathrm{~g}$ sized $L$. vannamei. Several authors have reported on the growth and survival of $L$. vannamei stocked in different salinity and densities in culture ponds (Samocha, 1999). As with survival rate, density also plays an important role in the growth of aquatic organisms (Araneda et al., 2008). While (Gaber et al., 2012) showed that, survival rate of 51.6 - $89 \%$ with density of 5, 15 and $25 \mathrm{shrimp} / \mathrm{m}^{2}$. (Araneda et al., 2008), reported a density of 90,130 and 180 shrimp / $\mathrm{m}^{2}$ with $76.1 \%, 68.9 \%$ and $65.9 \%$ survival rate respectively, where the survival rate decreased with increasing of the density. (Williams et al., 1996) and (Davis and Arnold 1998) reported the growth rate of $L$. vannamei between 0.5 and $0.95 \mathrm{~g} \mathrm{week}^{-1}$ at high salinity at density of 107 and $100 \mathrm{~m}^{-2}$. (Samocha et al., 2004) and (Sowers and Tomasso, 2006) get high growth rate of 1.17 and $1.23 \mathrm{~g}^{-1}$ week $^{-1}$ in low salinity, (Duy et al., 2012) at a salinity of $20-23$ ppt with a density of 10 shrimp $\mathrm{m}^{-2}$ found in Penaeus monodon a lower growth rate than in $30-33$ ppt salinity. The decreased of growth parameters and survival rates in shrimp farming and increased biomass production has also been reported (Samocha et al., 2004). This shows that interpersonal interactions have an effect on inhibiting growth and survival especially in increased density (Arnold et al., 2006). Although in the present study the cannibalism aspect has not been observed, often $L$. vannamei looks to prey on other shrimps that have died. When compared to the initial spread, the population density of shrimps decreased, greatly influencing the growth rate of the two density treatments by increasing the utilization of space (Arnold $\boldsymbol{e t} \boldsymbol{a l}$., 2006). More than a few authors have reported on the growth and survival of L. vannamei stock in different salinity and densities in culture ponds (Samocha et al., 2004). Finally our study revealed that the maximum production was obtained in pond with low stocking densities of high survival rates. An inverse relationship is known to exist between the stocking density and the survival and growth rates (Emmerson and Andrews 1981). Several authors described about the growth in shrimp culture systems based on stocking density (Maguire and Leedow 1983). In the present study was concluded that, good water quality parameter play a crucial role in shrimp culture ponds especially the low salinity $(15-38$ $\mathrm{psu})$ which was optimum for shrimp. Significant $(\mathrm{P}<0.05)$ differences 
were detected in the present study between the two nursery systems. In this connection, Wyban et al. (1995) found an increase in SGR values with smaller sizes of shrimp post-larvae, and a decrease from $4.5-5 \%$ / day for small sizes (1.43 - $1.83 \mathrm{~g} / \mathrm{pce}$ ) to $0.62-1.1 \%$ / day for bigger sizes $(11.2-11.81 \mathrm{~g} / \mathrm{pce})$ with better results at $30^{\circ} \mathrm{C}$ compared with 27 and 23 ${ }^{\circ} \mathrm{C}$. Ponce-Palafox et al. (1997) found that, SGR \% had ranged between 6 and $7.9 \%$. The average survival was 70 and $50 \%$ for Eldebba and Suez Canal Farms. Similar results were obtained by (Djumanto et al., 2016).

Table (3). Growth performance of white shrimp P. monodon in Eldebba and Suez Canal farm throughout the experimental period (120 days).

\begin{tabular}{|l|c|c|}
\hline Items & Eldebba farm & Suez Canal Farm \\
\hline Initial weight g & 0.002 & 0.002 \\
\hline Final weight gm & 40.0 & 35.20 \\
\hline Wight gain gm & 39.99 & 35.19 \\
\hline Wight gain gm/day & 0.33 & 0.29 \\
\hline Wight gain \% & 3999 & 1760 \\
\hline SGR & 8.25 & 8.15 \\
\hline Survival (\%) & 70.00 & 50.00 \\
\hline
\end{tabular}

\section{Feed utilization}

Table (4). Present Feed utilization of white shrimp L. vannamei in Eldebba and Suez Canal farms throughout the experimental period (120 days). FCR ( 1.7$)$ was significantly $(\mathrm{P}<0.05)$ lower in white shrimp in Eldebba fish farm than in Suez Canal farm (1.89) while Feed efficiency was higher 0.59 in Eldebba fish farm than in Suez Canal farm 0.53 and PER value was higher (1.64) in Eldebba fish farm compared with the lower value (1.48) recorded in Suez Canal Fish Farm. Gao et al. (2016) reported that the optimum dietary protein level for $L$. vannamei $(0.31-6 \mathrm{~g}$ size $)$ was $34 \%$ when a semi-purified diet was used. (Shahkar et al., 2014) reported that $33 \%$ dietary protein level is optimum for an optimal growth of $L$. vannamei (approximately $1-11 \mathrm{~g}$ size) when fish meal was used as the main protein source. (Apud et al. 1983) reported FCR value of 1.5 and 2.5 for artificial feeds is acceptable. (Wyban $\boldsymbol{e t}$ al. 1995) obtained that, FCR value of 1.8 when they nursed $L$. vannamei at a density of $50 \mathrm{pcs} / \mathrm{m}^{2}$. However, all feed utilization data (FCR, FER and PER) in Eldebba farm was significantly higher than in Suez Canal Farm. 
Table (4). Feed utilization of white shrimp L. vannamei in Eldebba and Suez Canal farm throughout the experimental period (120 days)

\begin{tabular}{|l|c|c|}
\hline Item & Elebba farm & Suez Canal farm \\
\hline Feed intake gm & 67.93 & 66.41 \\
\hline FCR (Feed conversion ratio) & 1.70 & 1.89 \\
\hline FER (Feed Efficiency Ratio) & 0.59 & 0.53 \\
\hline PER (Protein Efficiency Ratio) & 1.64 & 1.48 \\
\hline Protein intake & 24.31 & 23.77 \\
\hline
\end{tabular}

The optimum dietary protein level for maximum growth of $L$. vannamei can be affected by differences in shrimp size, stocking density, species of shrimp, culture system, and dietary protein sources. In the range of approximately $1 \mathrm{~g}$ sized shrimp, optimal growth was observed with 33 to $44 \%$ crude protein in diets when krill meal was used as a main protein source, whereas (Martinez-cordova et al. 2003) found that, the optimal protein level was $25 \%$ when L. vannamei $(1-17 \mathrm{~g}$ size $)$ was cultured in a pond system with three commercial diets containing 25,35 , and $40 \% \mathrm{CP}$ for 16 weeks. In a very high salinity condition $(60 \mathrm{~g} / \mathrm{L})$, the optimum dietary protein level was estimated to $46.7 \%$ when the L. vannamei (0.09 - $2.2 \mathrm{~g}$ size) was fed a semi-purified diet (Sui et al., 2015).

Generally, practical experimental diets have been used in this study covered most protein requirement for Penaeid shrimps. Most previous studies had used practical ingredients, i.e., fish meal and soybean meal as the main protein sources to increase or decrease the crude protein levels in the practical experimental diets. When fish meal is used as the main protein source to gradually increase the crude protein in diets for protein requirement study (Xia et al.2010_and Yun et al. 2016), the result might be over-estimated because of unknown growth factors in fish meal.

\section{Economical evaluations}

Table (5). Present of the economical evaluation of white shrimp production in Eldebba and Suez Canal farm. The result reveald that the cost of feeds accounted for the largest proportion (52 and $41 \%$ ) of the total cost of fish production for Eldebba and Suez Canal farm. This is followed by cost of fixed input PL (26 and $43 \%$ ), rent (10 and $6 \%$ ), solar (5 and 3 $\%$ ) and labor (5 and $5 \%$ ). This clearly shows that large fish farmers in the study area for purchase feeds spend amount of money. The fixed cost of production consists of cost of fixed assets such as feed, labour, rent and 
solar which accounted for 38000 and 58000 LE of total production cost for Eldebba and Suez Canal farms. This result is consistent with the finding of (Mansaray et al., 2018) from their studies on profitability on fish farming. Investments return LE / return LE cost 7.50 and 3.9 for Eldebba and Suez Canal Farms. White shrimp culture gives higher returns in money and food than rising of cattle, sheep and poultry (Tammaroopa, et al., 2016). In agreement with (Olaoye, et al., 2016). The result of the present study has been shown the higher production of white shrimp and accordingly the higher income which means that investment in this field of production is profitable. Finally, the present study concluded that white shrimp are may be a promising candidate for the brackish and salt water pond aquaculture in Egypt as well as other parts of the world.

Table (5). Average cost and return of White shrimp production

\begin{tabular}{|l|c|c|c|c|}
\hline \multirow{2}{*}{ Items } & \multicolumn{2}{|c|}{ Eldebba farm } & \multicolumn{2}{c|}{ Suez Canal Farm } \\
\cline { 2 - 5 } & Rate & Percent & Rate & Percent \\
\hline Costs feddan & & & & \\
\hline FL costs LE & 10000 & 26.32 & 25000 & 43.10 \\
\hline Labour and other costs LE & 20000 & 52.63 & 24000 & 41.37 \\
\hline Rent & 2000 & 5.26 & 3000 & 5.17 \\
\hline Solar & 4000 & 10.52 & 4000 & 6.89 \\
\hline Total costs LE feddan & 2000 & 5.26 & 2000 & 3.45 \\
\hline Income feddan LE & 38000 & & 58000 & \\
\hline Total production (ton /feddan) & 1.900 & & 1.750 & \\
\hline Price (LE) of one kg fish & 170 & & 165 & \\
\hline Total income LE/ feddan & 323000 & & 288750 & \\
\hline Net return LE/ feddan & 285000 & & 230750 & \\
\hline $\begin{array}{l}\text { Investmental return LE/ } \\
\text { return LE cost }\end{array}$ & 7.50 & & 3.97 & \\
\hline
\end{tabular}

This result is consistent with the finding of Tammaroopa et al. (2016) from their studies on profitability on fish farming. The rate of return per capital invested (RORCI) is the ratio of profit to total cost of production. 
It indicates what is earned by the business by capital outlay (Tammaroopa et al., 2016).

\section{Conclusion}

It could be concluded that stocking white shrimp at density 70000 / feddan was the best in terms of growth performance, feed utilization and economic evaluation under this experimental conditions.

\section{References}

Alcivar Warren, A., Meehan Meola, D., Won Park, S., ZHENKANG, Xu, Delaney, M. and Zuniga, G. (2007). Shrimp map: a low-density, microsatellite-based linkage map of the pacific whiteleg shrimp, litopenaeus vannamei: identification of sex-linked markers in linkage group 4. Journal of Shellfish Research, 26(4): 1259-1277.

Anand, P. S, Kohlib, M. P, Kumar, S. P and Pailanf, G. H. (2014). Effect of dietary supplementation of biofloc on growth performance and digestive enzyme activities in Penaeus monodon. Aquaculture 418419:108-115.

APHA, (1998). Standard Methods for the Examinations of Water and Wastewater. American Public Health Association, Washington, DC., New York, pp: 874.

Apud, F. D., Primavera, J. h. and Torres, P. L. (1983). Farming of prawns and shrimps. Southeast Asian Fisheries development Center. Extension Manual (5): 1-67.

Aquacop. (1984). Review of ten years of penaeid shrimp culture in Tahiti and New Caledonia (South Pacific). J. World Maricult. Soc,; 14: 73-91.

Araneda, M., Pérez, E. P. and Gasca-Leyva, E. (2008). White shrimp Penaeus vannamei culture in freshwater at three densities: Condition state based on length and weight. Aquaculture, 283:13-18.

Arnold, S. J., Sellars, M. J., Crocos, P. J. and Coman G. J., (2006). An evaluation of stocking density on the intensive production of juvenile brown tiger shrimp (Penaeus esculentus). Aquaculture 256:174-179.

Boyd, C. E. and Arlo, W. F. (1992). Pond monitoring and management. In: Fast, A. W and Lester, A. G. (Eds.), Marine shrimp culture: Principles and practices. Elsevier, Amsterdam, p. 36-42.

Boyd, C. E. (2015). Water quality: an introduction. Springer, New York.

Clifford, H. C. (1997). Manual de operación para el manejo de SuperShrimp en estanques. División de Servicios Técnicos. Super Shrimp, S.A. de C.V., Mazatlán. 105 p. 
Cohen, J., Samocha, T. M., Fox, J. M., Gandy, R. L. and Lawrence, A. L., (2005). Characterization of water quality factors during intensive raceway production of juvenile Litopenaeus vannamei using limited discharge and biosecure management tools. Aquacultural Engineering, 32, 425-442.

Coman, G. J., Crocos, P. J., Preston, N. P. and Fielder, D., (2002). The effects of temperature on the growth, survival and biomass of different families of juvenile Penaeus japonicus Bate. Aquaculture, 214:185-199.

Daniels, W. H., Abramo, D., Fonden, L. R. and Durant, M. D., (1995). Effects of stocking density and feed on pond production characteristics and revenue of harvested freshwater prawns Machrobrachium rosenbergii stocked as size-graded juveniles. J. world Aquacult, 26(1): $38-47$

Davis, D. A. and Arnold, C. R., (1998). The design, management, and production of recirculating raceway system for the production of marine shrimp. Aquacultural Engineering 17:193-211.

Djumanto, D., Ustadi, U., Rustadi, R., and Triyatmo, B., (2016). Feasibility study on the profitability of vannamei shrimp aquaculture on coastal area of Keburuhan Village, Purworejo Regency. Aquacultura Indonesiana 17(1):7-11.

Duy, H. N., Coman, G. J., Wille, M., Wouters, R., Quoc, H. N., Vu, T., Kim, D. T., Van, H. N. and Sorgeloos, P., (2012). Effect of water exchange, salinity regime, stocking density and diets on growth and survival of domesticated black tiger shrimp Penaeus monodon (Fabricius, 1798) reared in sand-based recirculating systems. Aquaculture 338-341:253-259.

Emmerson, W. D. and Andrews, B., (1981). The effect of stocking density on the growth, development and survival of Penaeus indicus Milne Edward larvae. Aquaculture 23:45-57.

Fast, A. W. and Lannan, J. E. (1992). Pond dynamic processes. In: FAST, A. W. and Lester, L. J. (Ed.). Marine shrimp culture: Principles and practices. Amsterdam: Elsevier Science Publishers,. p. 431-456.

Gaber M. M., Omar, E. A., Abdel-Rahim, M., Nour, A. M., Zaki, M. A. and Srour, T. M., (2012). Effects of stocking density and water exchange rates on growth performance of tiger shrimp, Penaeus semisulcatus cultured in earthen ponds. Journal Aquaculture Research \& Development 3:7 DOI: 10.4172/2155-9546.1000152. 
Gamal, M., Samadan, D. and Murwantoko, R. (2018). Production performance of whiteleg shrimp Litopenaeus vannamei at different stocking densities reared in sand ponds using plastic mulch. AACL Bioflux, , Volume 11, Issue 4.1213-1221

Gao, W., Tian, L., Hu, W., Luo, M., Liu, J., and Xu, Q., (2016).Optimal dietary protein level for the white shrimp (Litopenaeus vannamei) in low salinity water. Isr J Aquacult-Bamid.;68:1320.

Garza de Yta, A., Rouse, D. B. and Davis, D. A., (2004). Influence of nursery period on the growth and survival of Litopenaeus vannamei under pond production conditions. Journal of the World Aquaculture Society, 35(3): 357-365.

Gicos, A. (1993). Shrimp grow-out culture techniques in the Phillipines. In: Villegas, C. T., Castanos, M. T., Lacierda, R. B. (Eds.), Proceedings of the aquaculture workshop for Seafdec/Aqd training alumni, 8-11 September 1992, Seafdec Aquaculture Department, Iloilo, Philippines, $173 \mathrm{pp}$.

Hossain, M. I., Shahabuddin, A. M., Bhuyain, M. A. B., Mannan, M. A., Khan, M. N. D. and Ahmed, R., (2013). Scaling up of stocking density of tiger shrimp (Penaeus monodon) under improved farming system in Khulna Region of Bangladesh. American Journal of Experimental Agriculture 3(4):839-848.

Kachiga S. (1991) Statistical Analysis : A conceptual introduction Radius Press., 8 (16)

Lemos, D., Phan, V. N. and Alvarez, G., (2001). Growth, oxygen consumption, ammonia- $\mathrm{N}$ excretion, biochemical composition and energy content of Farfantepenaeus paulensis Pérez-Farfante (Crustacean, Decapods, Penaeidae) early post larvae in different salinities. Journal of Experimental Marine Biology and Ecology261: 55-74.

Lin, Y., and Chen, J., (2001). Acute toxicity of ammonia on Litopenaeus vannamei (Boone) juveniles at different salinity levels. J. Exp. Mar. Biol. Ecol., 259:109-119.

Lin, Y. and Chen, J., (2003). Acute toxicity of nitrite on Litopenaeus vannamei (Boone) juveniles at different salinity levels. Aquaculture, 224:193-201.

López-Martínez, J., Arreguín-Sánchez, F., Hernández-Vázquez, S., García-Juárez, A. R. and Valenzuela-Quiñonez, W., (2003). Inter annual variation of growth of the brown shrimp Farfantepenaeus 
californiensis and its relation to temperature. Fisheries Research, 61: 95-105

Maguire, G. B. and Leedow, M. I., (1983). A study of the optimum stocking density and feed rate for school prawns Metapenaeus macleayi in some Australian brackish water farming ponds. Aquacult., 30: 285297.

Mansaray, M., Hayfor, A. G., Xiaojun, J., Lin, Z. and Xinhua,Y., (2018). Economic Analysis of White-Leg Shrimp (Penaeus vannamei) Production Case Study: Rudong County of Nantong City, Jiangsu Province, China .Asian Journal of Agricultural Extension, Economics \& Sociology 26(4): 1-13, 2018;

Martinez-Cordova, L. R., Campana Torres, A., and Porchas-Cornejo, M. A., (2003). Dietary protein level and natural food management in the culture of blue (Litopenaeus stylirostris) and white shrimp (Litopenaeus vannamei) in microcosms. Aquac Nutr.;9:155-60.

Mena-Herrera, A., Gutierrez-Corona, C., Linan-Cabello, M. and SumanoLopez, H., (2006). Effects of stocking densities on growth of the Pacific white shrimp (Litopenaeus vannamei) in earthen ponds. The Israeli Journal of Aquaculture-Bamidgeh 58(3):205-213.

Neal, R. S., Coyle, S. D. and Tidwell, J. H., (2010). Evaluation of stocking density and light level on the growth and survival of the Pacific white shrimp, Litopenaeus vannamei reared in zero-exchange systems. Journal of the World Aquaculture Society 41(4):533-544.

Nour, A. A., Zaki, M. A., Abdel-Rahim, M. M., and Srour, T. M., (2004). Feed Utilization Of Marine Shrimp Penaeus Semisulcatus Post-Larvae Reared In Two Nursery Systems With Different Stocking Sizes. Egyptian Journal Of Aquatic Research. VOL. 30(B), 2004:390-405

NRC (1993). Nutrient requirements of warm water fishes and shellfishes. National Academy Press, Washington DC.

Olaoye, O. J., Ojebiyi, W. G., Opele, A. I., and Baiyewu, A. K., (2016). Socio economic analysis of small scall fish farmes in Liaro agriculture extension zone Ogum state, Nigeria . Journal of Agriculture , Forrestry and fisheries, Volume 15, Number $2: 65-74$

Ponce-Palafox, J. T., Martínez-Palacios, C. A., and Ross, L. G., (1997). The effects of salinity and temperature on the growth and survival rates of juvenile white shrimp Penaeus vannamei Boone 1931. Aquaculture 157:107-115. 
Rosas, C., Cuzon, G., Taboada, G., Pascual, C., Gaxiola, G., and Van Wormhoudt, A., (2001). Effect of dietary protein and energy levels on growth, oxygen consumption, haemolymph and digestive gland carbohydrates, nitrogen excretion and osmotic pressure of Litopenaeus vannamei (Boone) and L. setiferus (Linne) juveniles (Crustacea, Decapoda; Penaeidae). Aquac Res.;32:531-47.

Sadek, S., Rafael, R., Shakouri, M., Rafomanana, G., Ribeiro, F. L. and Clay, J., (2002). Shrimp Aquaculture in Africa and the Middle East: The Current Reality and Trends for the Future. Report prepared under the World Bank, NACA, WWF and FAO Consortium Program on ShrimpFarming and the Environment. Work in Progress for Public Discussion. Published by the Consortium. 42 pages.

Samocha, T., Addison, M., Lawrence, L., Craig, A., Collins, F. L., Castille, W. A., Bray, C. J., Davies, P. G., Lee, G., Wood and F., (2004). Production of the Pacific white shrimp, Litopenaeus vannamei, in highdensity greenhouse-enclosed raceways using low salinity groundwater. Journal of Applied Aquaculture 15:1-19.

Samocha, T. M., Lawrence, A. L., Bray, W. A., Collins, C. A., Castille, F. L., Lee, P. G. and Davies, C. J., (1999). Reduction of marketable Litopenaeus vannameiin green house enclosed raceways in the Arizona desert using ground saline water. In: Book of Abstracts. World Aquacult, Soc. Ann. Conf., Sydney, Australia, 669.

Shahkar, E., Yun, H., Park, G., Jang, I. K., Kim, S. K. and Katya, K., (2014). Evaluation of optimum dietary protein level for juvenile whiteleg shrimp (Litopenaeus vannamei). J Crustacean Biol.;34:552-8.

Sivanandavel P. and Soundarapandian, P., (2010). Effect of stocking density on growth and survival of cage reared Indian white shrimp Penaeus indicus (H. Milne Edwards) at Vellar estuary. Asian Journal of Agricultural Sciences 2(1):1-4.

Soundarapandian, P. and Gunalan, B., (2008). Recent technology for the survival and production of giant tiger shrimp Penaeus monodon along south east coast of India. International Journal of Zoology and Research, 4(1), pp 21-27.

Sowers, A. D. and Tomasso, J. R., (2006). Production characteristics of Litopenaeus vannamei in low-salinity water augmented with mixed salts. Journal of the World Aquaculture Society 37:214-217.

Sui, L., Ma, G. and Deng, Y., (2015). Effect of dietary protein level and salinity on growth, survival, enzymatic activities and amino-acid 
composition of the white shrimp Litopenaeus vannamei (Boone, 1931) juveniles. Crustaceana.;88:82-95.

Tacon, A. G. J. (2002). Thematic Review of Feeds and Feed Management Practices in Shrimp Aquaculture; In Report Prepared for the World Bank, NACA, WWF and FAO Consortium Program on Shrimp Farming and the Environment,

Tammaroopa, K., Suwanmaneepong, S. and Mankeb, P. (2016). Socioeconomic factors influencing white shrimp production in Chachoengsao Province, Thailand. International Journal of Agricultural Technology. 12(7.2):1809-1820.

Wang, X., Ma, M., Dong, S., and Cao, M., (2004). Effects of salinity and dietary carbohydrate levels on growth and energy budget of juvenile Litopenaeus vannamei. J. Shellfish Res.,23: 231-236.

Williams, A. S., Davis, D. A. and Arnold, C. R., (1996). Densitydependent growth and survival of Penaeus setiferus and Penaeus vannamei in a semi-closed recirculating system. Journal of the World Aquaculture Society 27:107-112.

Wurmann, C. G., Madrid, R. M. and Brugger, A. M. (2004). Shrimp farming in Latin America: Current status, opportunities, challenges and strategies for sustainable development. Aquaculture Economics and Management 8(3-4):117-141.

Wyban, J., Walsh, W. and Godin, D., (1995). Temperature effects on growth, feeding rate and feed conversion of the Pacific white shrimp (Penaeus vannamei). Aquacult., 139: 267-279.

Xia, S., Li, Y., Wang, W., Rajkumar, M., Vasagam, K., and Paramasivam, K., (2010). Influence of dietary protein levels on growth, digestibility, digestive enzyme activity and stress tolerance in white-leg shrimp, Litopenaeus vannamei (Boone, 1931), reared in high-density tank trials. Aquac Res.;41:1845-54.

Xu, Z. and Boyd, C. E., (2016). Reducing the monitoring parameters of fishpond water quality.Aquaculture,465, 359-366.

Yun, H., Shahkar, E., Katya, K., Jang, I. K. and Bai, S. C., (2016). Effects of bioflocs on dietary protein requirement in juvenile whiteleg shrimp, Litopenaeus vannamei. Aquac Res.;47:3203-14.

Zaki, M. A, Nour, A. A., Abdel-Rahim, M. T. M. and Srour, T. M., (2004). Effect of stocking density on survival, growth, feed utilization and production of marine shrimp Penaeus semisulcatus in earthen ponds. Egyptian Journal of Aquatic Research 30(B):429-442 


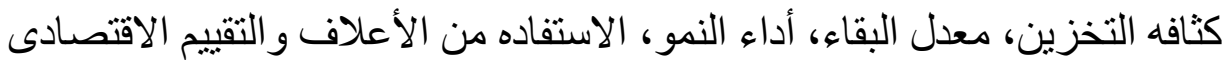

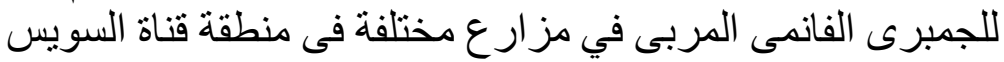

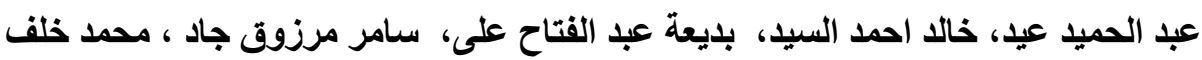

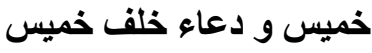
كلية الزر اعة جامعة قناة السويس- الاسماعيلية 41522 جمهورية مصر العربيه

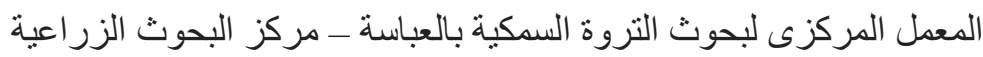

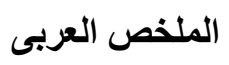

أجريت دراستان لتقييم أداء النمو، الاستفاده من الأعلاف، ومعدل البقاء البقاء والتكلفة الاقتصادية

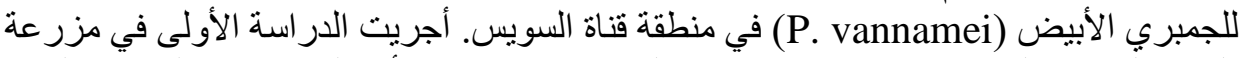

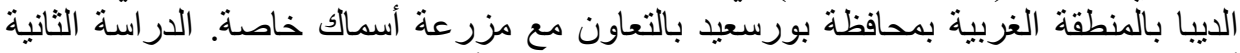

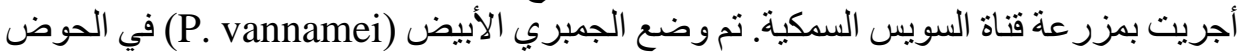

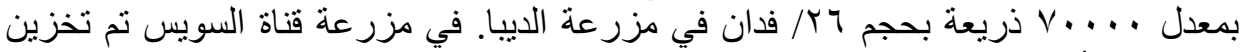

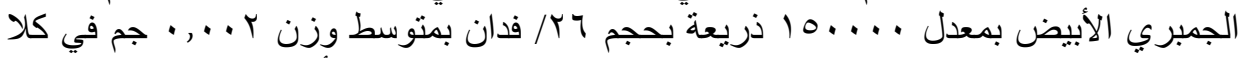

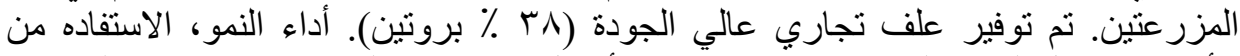

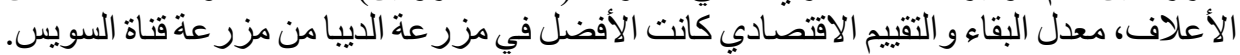

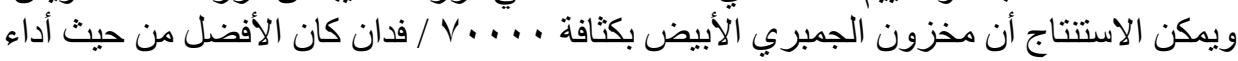

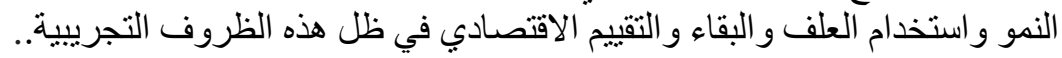

